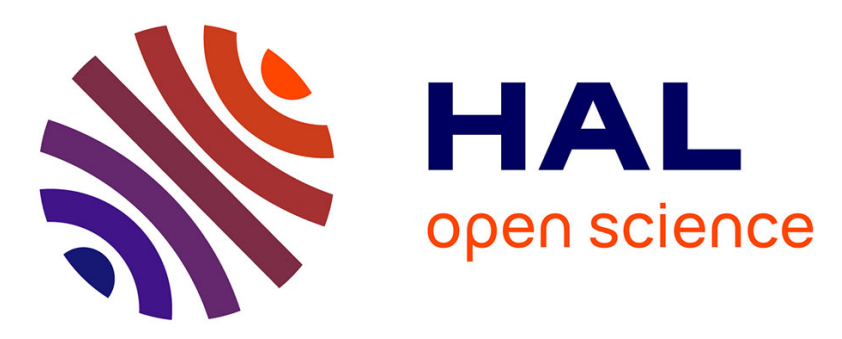

\title{
Designing for Motivations: Building on Two Local Communities Cases
}

Veronica Cruciani, Myriam Lewkowicz

\section{To cite this version:}

Veronica Cruciani, Myriam Lewkowicz. Designing for Motivations: Building on Two Local Communities Cases. Maurizio Teli (ed.), Chiara Bassetti (ed.) Becoming a Platform in Europe: On the Governance of the Collaborative Economy, 2021, 10.1561/9781680838411.ch6 . hal-03404724

\section{HAL Id: hal-03404724 \\ https://hal.science/hal-03404724}

Submitted on 26 Oct 2021

HAL is a multi-disciplinary open access archive for the deposit and dissemination of scientific research documents, whether they are published or not. The documents may come from teaching and research institutions in France or abroad, or from public or private research centers.
L'archive ouverte pluridisciplinaire HAL, est destinée au dépôt et à la diffusion de documents scientifiques de niveau recherche, publiés ou non, émanant des établissements d'enseignement et de recherche français ou étrangers, des laboratoires publics ou privés. 


\section{Designing for Motivations: Building on Two Local Communities Cases}

\section{By Veronica Cruciani and Myriam Lewkowicz}

Copyright (C) 2021 Veronica Cruciani and Myriam Lewkowicz DOI: 10.1561/9781680838411.ch6

The work will be available online open access and governed by the Creative Commons "Attribution-Non Commercial” License (CC BY-NC), according to https://creativecommons.org/licenses/by-nc/4.0/

Published in Becoming a Platform in Europe - On the Governance of the Collaborative Economy by Maurizio Teli and Chiara Bassetti (eds.). 2021. ISBN 978-1-68083-840-4. E-ISBN 978-1-68083-841-1.

Suggested citation: Veronica Cruciani and Myriam Lewkowicz. 2021. "Designing for Motivations — Building on Two Local Communities Cases" in Becoming a Platform in Europe - On the Governance of the Collaborative Economy. Edited by Maurizio Teli and Chiara Bassetti. pp. 110-135. Now Publishers. DOI: 10.1561/9781680838411.ch6.

\section{now \\ the essence of knowledge}




\subsection{Introduction}

In this chapter, we discuss the nuances of the terms sharing and sharing economy by looking at practical activities falling under the concept of "sharing", and the technologies related to those activities. Specifically, we are interested in how technologies can support groups of people that call themselves "communities", and reversely how communities shape the technology when adopting a triple-bottom line instead of a single profit line (Elkington, 1997) - getting profit, improving society, and respecting the environment, without emphasizing one motivation over the others.

Our interest for local communities comes from our reading of literature about food resilience and projects by communities of farmers, village's civilians, or little 
entrepreneurs (Light and Miskelly, 2015; Norström et al., 2020; Ostrom, 1990; Teli et al., 2017). We investigated two local communities. The first is an engineering students' association active in sustainability and social aid fields. The second one is a village community halfway between a volunteering-based association and a little enterprise exclusively selling local products. When looking at the missions and goals of the two associations, we found out that any form of capitalism or platform economy does not fully frame their activities. Members of both communities neither feel represented by the existing social media and tools available on Google, nor by the sharing economy platforms' philosophy, or generally any existing profitbased platform.

Bringing some practical examples, these associations are particularly concerned by the protection of members and customers' data from being sold; both associations are based exclusively on selling local or $0 \mathrm{~km}$ products, but they never ascribed this choice inside some doctrine or ideology: they just co-decided that this was the best solution to fully realize themselves as associate members and citizens. Further examples are the attempts of the students' association to find alternatives to social media and advertisements to sponsor, recruit, and engage students, and their choice of using Discord instead of Whatsapp. In fact, Discord is a proprietary freeware that offers instant messaging and VoIP features. First used by gamers, it reached 100 million active users in 2020. According to student association's members, the advantages compared to Whatsapp are privacy, as it is not "owned by Facebook", and the possibility to create a thematic channel inside a group, with participants voluntarily joining if they are part of the group.

In the remainder of this chapter, we will first discuss the sharing economy for local communities, before presenting the two communities that we have observed, delineating their vision and mission, their structure, and the technological artifacts they are using. We then analyze the motivations of the members of these communities to participate, identifying four areas of motivation: sustainability, sociability, politics, and economy. These findings lead us to identify implications for designing for local communities in the forms of four personas.

\subsection{Sharing in Local Communities}

The sense of community, which is the sine qua non of every community, can be seen as made up of four elements (McMillen et al., 2020): membership, influence, fulfillment of needs, and shared emotional connection. This sense of community is really contrasting with the platform economy models that are often related to "sharing economy": A platform, or a form of data usage that is capitalized, hardly promotes a sense of community and inclusiveness. In fact, capitalized platforms 
foresee transcending individual needs to recognize a common line of action (Keyes et al., 2019).

This contrast between the sense of a community and the "sharing economy" may come from the fact that the term sharing is extremely broad and ambiguous. It could embrace different forms of sharing (Encyclopedia Britannica): reciprocity, demand sharing (Woodburn et al., 1998), prosocial behaviours in general, which embraces mutualism (Feigin et al., 2014) and sharing nicely.

Sharing nicely is the phenomenon we want to explore to offer suggestions on how to design for local communities. Sharing nicely has been used for the first time by the anthropologist Woodburn et al. (1998) in contraposition with the demand sharing. It might also be called altruism; it is innate for more developed species if not just the human (Lay and Hoppmann, 2015), and partly interiorized. Sharing nicely is aligned with the work by Mauss (2002) on gift giving. A gift is a connector between the giver and the receiver, acquiring among all, a symbolic meaning, going beyond the object itself, contributing to the strength of the community and building empathy among strangers. The mechanism to hold this is made of implicit giving and giving back. As Mauss writes: "In all this there is a succession of rights and duties to consume and reciprocate, corresponding to rights and duties to offer and accept. Yet this intricate mingling of symmetrical and contrary rights and duties ceases to appear contradictory if, above all, one grasps that mixture of spiritual ties between things that to some degree appertain to the soul, and individuals, and groups that to some extent treat one another as things" (Mauss, 2002, p. 17). This form of prosocial behavior might be considered as an elaborated form of reciprocity, with symbolic meanings and a more complex organization than the simple "returning the service" characterizing reciprocity. While psychologists still debate about the existence of pure altruism (Feigin et al., 2014), the gift exchange might be considered one of the prosocial behaviors.

The relationships between different technologies and social practices in a community have been largely discussed, focusing on either their description, their conceptualization, or the design of technologies to better support social practices. Close to our interest in the critique of the capitalistic model of platforms for the sharing economy, Carroll and Beck (2019) have shown how to create a complementary service to platform capitalism, that they called platform collectivism. Platform collectivism is characterized by ownership and shared data (in contraposition of data possession), transparency and openness (in contraposition of buying and selling data), flat hierarchy, and peer-to-peer interaction (instead of pyramidal hierarchy and profit driven interactions). The central point in platform collectivism is to increase the value of data by giving priority to stakeholders' values instead of inserting or proposing new values for the platform. When data reflects stakeholders' values and needs, they are shared not just by the ones directly interested to them, 
but even by the community at large, increasing their visibility and access, as well as their educative value for local residents (Avram et al., 2019; Carroll and Beck, 2019). However, before co-designing a platform conceived in a collective way, it is necessary to assess if the community, the artifacts, and the relationships between the two are fertile for a collective use of the platform instead of a capitalistic one (Bødker et al., 2016).

Two interesting conceptualizations have been offered to describe the relationships between a community and its artifacts. Rossitto et al. (2014) suggest the concept of a "constellation of technologies", which is the entanglement of a group's private and shared artifacts, interactions, knowledge and skills, which take place to realize a performance. Bødker et al. (2016) define a "community artifact ecology" as "the particular constellation of artifacts that a community owns, has access to and uses in its activities. It is characterized by a high degree of shared understanding of the core activities and the role of the artifacts within the ecology" (Bødker et al., 2016, p. 1144). The concept of community artifact ecology, then, includes the idea of a common level of knowledge about the artifacts-in-use. For example, we found that all students from the association that we have observed were highly skilled in informatics and at the same time knew a lot about sustainability and data protection, whereas the members of the village association were more prone to face-to-face relationships and low technology deployment. Thus, even if both associations have almost overlapping aims, they deploy very different artifacts ecologies, engaging with them in different ways, and using different sets of skills and knowledge.

In order to investigate these ecologies or constellations, a deep understanding of member's practices is required, especially the embodiment, domestication, routinization, overuse or, reversely the abandonment of artifacts. In the best cases, an appropriate community artifact ecology should transform a behavior into a social practice (Kuutti et al., 2014). The introduction and appropriation of technology is particularly interesting to study for "low-tech" communities, in particular the way this appropriation could empower a community. For instance, Jayathilake et al. (2017) have studied the introduction of technology in subsistence agriculture, outlining how some forms of technology deployment give more autonomy and tools and knowledge to make decisions to a part of the community - like the Sri Lanka's farming one - that is usually not taken into account.

\subsection{Two Local Associations Dealing with Food}

The two associations we met are very different in their composition and their administration, but they share the same interest in community food and economic resilience. Both of them act for the reinforcement of local communities, work 
towards a socio-environmental transition, wish to gather multiple and diverse actors who have the same aim and ideals, and share an interest for participation and local democracy.

\subsubsection{A Student Association}

The student association, Ulisse, literally stands for "local union for social, solidary and environmental engineering" (Union Locale d'Ingénierie Sociale, Solidaire et Environnementale, in French). Ulisse was created in 2019 and is formed of 90 active members (and 137 participating in online group chats). It is the result of the merger of five student associations related to the promotion of a sustainable world, united world, and local ecological initiatives. The document presenting the merger (displayed on the facebook pages of the different associations) indicates that these five associations decided to meet because they all have similar values and projects, and had identified that this could lead to competition problems for subsidies, and waste of time and energy in administrative tasks. Ulisse conciliates the environmentalist and the locality causes in particular by managing projects aimed at supporting local producers and farmers. Most of the time, these farmers come from the local associations of farmers mostly linked to permaculture and organic agriculture, firmly opposing modern methods to cultivate and extensive agriculture.

\subsubsection{A Village Association}

The village association, Le Cerf à Trois Pattes (shortened into Cerf in the rest of the document), was created in 2018 after the failure of the local bakery. The reason for failure was very simple: in a 550 souls' village between two big cities - Reims and Tours - a bakery has to hire at least 4 people and be available from 7.00 to 18.00 to guarantee the service. As a result, the costs were higher than the gains.

From this experience, some people questioned themselves on how to make the village survive ("we would like that people here do not feel forced to emigrate to town because there are no services and opportunities or facilities"), on one side avoiding that young people abandon it, offering jobs, and on the other, keeping the elderly engaged with public life. After several meetings, the outcome was a hybrid activity that has put together volunteering and regular employment, with firstly social and then economic goals.

\subsection{Data Collection and Method}

Participant observation (DeWalt et al., 1998) was adopted to study Ulisse: the first author, who came to Troyes as an exchange student, became a member of 
Ulisse, actively participating in its initiatives, in order to gain their trust and have a deeper insight of both their culture and their community artefact ecology. We conducted six semi-structured interviews, and we participated in a general assembly. The COVID-19 pandemic made it impossible to keep performing active participation, so we pursued a virtual ethnography of both their social media and their Discord conversations during six months (approximately 1600 Discord messages), going on interacting with them while the university was closed and most of the activities suspended (Table 6.1).

During the lockdown, the second author met one member of Cerf (during a meeting of another association), who was telling how prolific Cerf was during the pandemic since it was taking care of each customer's order sending it in their own house. The second author then asked if it would be possible for the first author to come to the village and meet the members of Cerf. Indeed, since both associations presented very similar base ideas but very different ways of organising, we took the opportunity to follow Cerf to complement our findings coming from our work with Ulisse. We conducted five semi-directive interviews, observed how the activities were performed (we joined a local touristic activity and observed one members' assembly) when we visited the village during four days (Table 6.2).

We transcribed the interviews and our notes taken during field observations, and conducted a thematic analysis (Braun and Clarke, 2006), looking at the motivations of the associates, and the use of personal and community artifacts to realize community aims.

Indeed, since we outlined how sharing nicely through platforms is not an opportunism/altruism phenomena, but rather a multifaceted culture-dependent integration of both (Belk, 2014), and a complex assimilation of social motives and identities (Ryan and Deci, 2000), it is necessary to point out personal motives and how they are connected to the use of artifacts inside the community.

\subsection{Findings}

\subsubsection{Organization and Activities of Ulisse}

Ulisse has a president, two vice presidents, one for the projects, one for the contacts and the partnerships, one treasurer, one vice treasurer, one secretary, and two persons in charge of communication. Ulisse members are recruited and attracted through different means; first, during the general assembly, where at the start of each semester they introduce themselves and their projects to all the students. 
Table 6.1. Synthesis of data collection for Ulisse.

\begin{tabular}{|c|c|c|c|c|}
\hline Role & Technique & Duration & Place & Focus \\
\hline Vice president & $\begin{array}{l}\text { Face-to-face } \\
\text { interview }+ \\
\text { notes }\end{array}$ & 30 minutes & $\begin{array}{l}\text { University } \\
\text { room }\end{array}$ & $\begin{array}{l}\text { General data } \\
\text { and facts about } \\
\text { Ulisse. His } \\
\text { aims in the } \\
\text { association }\end{array}$ \\
\hline Vice president & $\begin{array}{l}\text { Online } \\
\text { interview }\end{array}$ & $\begin{array}{l}1 \text { hour and } 12 \\
\text { minutes }\end{array}$ & $\begin{array}{l}\text { Online } \\
\text { (Discord video } \\
\text {-call) }\end{array}$ & $\begin{array}{l}\text { Ulisse's use of } \\
\text { technology and } \\
\text { apps, Ulisse's } \\
\text { changes after } \\
\text { and during } \\
\text { COVID } 19\end{array}$ \\
\hline $\begin{array}{l}\text { Univ. creator } \\
\text { of a ridesharing } \\
\text { initiative }\end{array}$ & $\begin{array}{l}\text { Face to face }+ \\
\text { notes double } \\
\text { check after the } \\
\text { interview }\end{array}$ & 30 minutes & $\begin{array}{l}\text { Ulisse's room } \\
\text { at University }\end{array}$ & $\begin{array}{l}\text { General facts } \\
\text { about Ulisse } \\
\text { and the } \\
\text { university } \\
\text { regarding the } \\
\text { ride sharing } \\
\text { initiative: } \\
\text { problems and } \\
\text { ideation phase }\end{array}$ \\
\hline $\begin{array}{l}2 \text { vice } \\
\text { presidents, } 1 \\
\text { treasurer and } \\
\text { three other } \\
\text { members }\end{array}$ & $\begin{array}{l}\text { Presence } \\
\text { during the } \\
\text { assembly }+ \\
\text { informal } \\
\text { conversation } \\
\text { after the } \\
\text { assembly }\end{array}$ & 45 minutes & Univ. hall & $\begin{array}{l}\text { Knowing new } \\
\text { projects, } 2020 \\
\text { plan and } \\
\text { getting in } \\
\text { touch with } \\
\text { members self- } \\
\text { introduction }\end{array}$ \\
\hline $\begin{array}{l}\text { Ulisse Discord } \\
\text { members }\end{array}$ & $\begin{array}{l}\text { Written } \\
\text { question on } \\
\text { Discord group } \\
+ \text { screenshot } \\
\text { of each reply }\end{array}$ & // & Online & $\begin{array}{l}\text { Knowing } \\
\text { motivations, } \\
\text { and } \\
\text { self-perception } \\
\text { as an engineer } \\
\text { and Univ. } \\
\text { member }\end{array}$ \\
\hline $\begin{array}{l}\text { Ulisse } \\
\text { members }\end{array}$ & $\begin{array}{l}\text { Informal } \\
\text { interviews to } 5 \\
\text { members after } \\
\text { the 1st meeting } \\
\text { for a particular } \\
\text { project }\end{array}$ & $\begin{array}{l}\text { Around } 30 \\
\text { min }\end{array}$ & $\begin{array}{l}\text { In person, } \\
\text { group } \\
\text { conversation in } \\
\text { University } \\
\text { room }\end{array}$ & $\begin{array}{l}\text { Break the ice, } \\
\text { opinions about } \\
\text { Ulisse and the } \\
\text { association } \\
\text { with the } \\
\text { university }\end{array}$ \\
\hline
\end{tabular}


Table 6.2. Synthesis of data collection for Le Cerf à 3 pattes.

\begin{tabular}{|c|c|c|c|c|}
\hline Role & Technique & Duration & Place & Focus \\
\hline President & Interview & $72 \mathrm{~min}$ & $\begin{array}{l}\text { Online (video } \\
\text { call Whatsapp) }\end{array}$ & $\begin{array}{l}\text { General } \\
\text { information about } \\
\text { association and } \\
\text { artifacts the } \\
\text { association uses }\end{array}$ \\
\hline President & $\begin{array}{l}\text { Interview while } \\
\text { visiting the } \\
\text { association's } \\
\text { building }+ \\
\text { notes (mobile) }\end{array}$ & $\begin{array}{l}1 \text { hour } \\
\text { approx. }\end{array}$ & $\begin{array}{l}\text { Guided visit to } \\
\text { the } \\
\text { association's } \\
\text { venue }\end{array}$ & $\begin{array}{l}\text { Visiting the } \\
\text { venues, getting in } \\
\text { touch with the } \\
\text { members, } \\
\text { understanding } \\
\text { vision and mission }\end{array}$ \\
\hline Members & Interviews & $\begin{array}{l}\text { Several } \\
\text { short } \\
\text { interviews }\end{array}$ & $\begin{array}{l}\text { House of the } \\
\text { member and } \\
\text { e-shop of the } \\
\text { association }\end{array}$ & $\begin{array}{l}\text { Field observation, } \\
\text { technology use } \\
\text { from elderly } \\
\text { associates }\end{array}$ \\
\hline Activity owner & Interviews & $\begin{array}{l}40 \text { min } \\
\text { approx. }\end{array}$ & $\begin{array}{l}\text { WhatsApp } \\
\text { video call }\end{array}$ & $\begin{array}{l}\text { Presentation of his } \\
\text { activity, work } \\
\text { deontology and } \\
\text { why joining Cerf }\end{array}$ \\
\hline Website creator & $\begin{array}{l}\text { Face to face }+ \\
\text { recorded } \\
\text { interview }\end{array}$ & 37 minutes & $\begin{array}{l}\text { Web design } \\
\text { company } \\
\text { venue }\end{array}$ & $\begin{array}{l}\text { Understanding } \\
\text { web design, } \\
\text { economical and } \\
\text { marketing aspects } \\
\text { of Cerf }\end{array}$ \\
\hline
\end{tabular}

Once students decide to join, they sign-in with their e-mail address and telephone number during or after the meeting. Students can also contact the associates, generally the leader or one of the vice presidents, by e-mail or Facebook, and they give their email address and phone number in order to be contacted again and, especially, added to the Discord channels. Indeed, even if Whatsapp and Facebook Messenger are used among some members for personal or informal communications, the official communication tool inside the association is Discord.

Decision-making happens face to face for most important decisions, and via Discord, where any member can submit a new idea to the vote and the majority wins. For important decisions (funding a project, leadership vacancy ...), they use the dot vote and the three winning proposals are re-evaluated, possibly merged and then (maybe) re-voted. The vice-president calls this process "the one that is really democratic". 
Three kinds of meetings are organized:

- Project meetings, in which they discuss how to realize a project after it has been approved on Discord: people interested just need to join the meeting and the project channel.

- Head's meeting gathering the presidents, vice presidents and the accountant for monitoring the projects and their costs, or to check their progress. Most of the time, these meetings take place on Discord, but when an issue is raised for which no consensus can easily be found, an in-person meeting is organized.

- General meetings: official general assemblies, and thematic presentations.

Ulisse has different activities: projects, debates and lectures, and events.

Projects can be of different types (engineer without border, influencer - for instance supporting a hitchhiker and his YouTube channel, local food consumption, ride sharing). Project work is mainly accomplished using Discord, in which each project has a specific channel. Any student can decide to join a channel dedicated to a project. The proposer of a project will assume the role of coordinator of the Discord channel. When a project is concluded, the channel is dismissed. Ulisses members also create thematic Facebook pages for their projects. An example is the "Potager" (vegetable garden) group, in which members share information about University allotment, how to cultivate and how to compost, or the group "Panier" (basket), in which each Wednesday people put orders for seasonal and local food. The payment is done once they pick up the basket: in some exceptional cases the basket is left to the students common room (which is run by another association) and the sum is handed to the person in the entrance.

Debates and lectures are an important part of their activity and well reflect Ulisse's ideology - which they want to diffuse - and activism. They are held by an expert and are attended by the members who are passionate on the many topics that are discussed. Sometimes, associates intervene in external lectures to tell their experience or what they do for the community (ex: promote an "eco-responsible" food consumption).

The last type of activity are the events. Usually they do it "Just to have some fun" or to raise money for their projects. It might consist of any kind of initiative: selling crepes, mask parties, hitchhiking marathons, etc.

\subsubsection{Ulisse's Ecology of Artifacts}

When it comes about the artifacts they use, Ulisse has an Instagram and a Facebook account accessible to all the members. Although they would rather not use social 
media, especially "If owned by Zuckerberg" (Ulisse vice president), they use social media to:

- Advertise their events (debates, lectures, public speeches, parties charity fundraising and projects' fundraising) and projects.

- Invite to "presentation meetings" and recruit new members.

- Communicate about social engagement, environment and sustainability, especially through posters, ads and leaflets created with a shared Canva account.

- Show the weekly basket of available vegetables to order online and buy at the University every Wednesday.

- Present stories on Instagram, and follow other people.

When it comes to official communications among members, they use Discord since it is possible to create thematic channels and privacy is respected. There, they propose projects, meetings and thematic conversations: each project has a dedicated channel and ends with a face-to-face meeting. Every member of Ulisse has access to the Discord group, and sometimes, even non-members can join some channels if they have the possibility to contribute somehow to the association. They collectively participate in the conversation, and they make "group calls" when they cannot do it in person. Only some of the newcomers are familiar with Discord (usually gamers), so others take time to show the newcomers how to use it. Some others do not get familiar and they rather keep themselves updated through friends or Messenger conversations.

Lastly, as one goal of Ulisse is to spread as much knowledge as possible, each week a different member records a fifteen minutes podcast in a studio made available by the university (examples of topics are: collapsology, permaculture, ocean pollution, freedom of speech in France). The podcast is publicized on Facebook and the university radio. It is accessible free for all Ulisse's members.

\subsubsection{Organization and Activities of Cerf}

Le Cerf à 3 pattes owns a shop, where they sell food, drinks and handmade products from 30 local producers. If a consumer wants to substitute the mainstream products from big chains (toothpaste, soaps, Coca Cola etc.) they can find alternatives there. The shop is temporary and has an outdoor part with flowers and plants, and an indoor part. They want to base their selling only on local and well-selected products which production respects nature; they carefully choose their partners and visit their places. They even pay attention to the way their partners present themselves to sellers and engage clients. In the shops, there is the highest attention to the way 
packaging is used (at the minimum level and often of recycled materials), every product has the origin, and the main features reported: a casual customer would easily understand the boutique identity. Another aspect of their economy is that they want to promote local and sustainable tourism, especially out of the usual enogastronomic tourism, since their area is famous for Champagne production. They would like to prove that there is a lot more to be discovered like the mountain, panoramas, countryside tours, outdoor sports etc. Children and families are their main targets and the activities they offer foresee contact with nature, discoveries and learning by doing (and having fun).

Out of the shop itself, the associates organize a "socio-cultural or touristic entertainment, proposed at least once per month: convivial dinner, theater, concert, night walk, philosophic café, producers' open air market ... we're among 60 to 500 participants, depends on the event".

They also have a meeting room "recycled" from the local school's space that is used for decision-making processes.

When it comes to ordering, an offline solution is still used for elderly and people who usually swing by the shop. They use a paper-based list with all the seasonal items they might order: the customer makes the order and handles it to the shop assistant in the boutique.

\subsubsection{Cerf's Ecology of Artifacts}

In terms of artifacts, Cerf has a Facebook page and a website to give them visibility, and a newsletter sent every two weeks to keep the most affectionate customers informed.

Facebook is mainly used to sponsor the events that are organized and the touristic or educational activities. Some special announcements are made for last minute selling and special offers presented as a full-page picture with few words to explain the post. The ones who have access to the shop's laptop run the page and by the closest associates; it gives a sense of belonging and creates interest and curiosity among association's sympathizers but even enthusiasts of local products and sustainable tourism. Paraphrasing what the associates said in their meeting, they do not share the page management but they share the involvement, the values and the knowledge (especially related to local economy and environment) among whoever is interested in.

A Google folder is used for listing the available products; the association's administrators in charge of selling the products are the ones who manage this folder.

Customers who see these announcements, online documents, or receive the newsletter and want to buy some products, can put an order by sending an email and paying by transferring money to the bank account of the association. 
The website has involved a web design agency and is now run by the President and the most motivated and expert associates. The agency followed the directions given by the President and tried to create a website that is easy to run (in their words: "very front office based"). The website presents the association in order to attract people, and gives the possibility to get in touch with Cerf's staff, to ask questions and know the events hosted by the association (Facebook posts about the events are depicted). But the aim of the website is mostly to sell the products from the little autonomous local enterprises that cooperate with the association.

\subsection{Analysis - Motivations for Sharing Nicely}

What has been clear since the very first interviews was that the economic activity of the association and the members' aims were perceived as "for good" and ethical: there was no perception of discrepancy between opportunistic goals (meet new people, make money and learn new skills), and altruistic ones (environment, society and volunteering).

An emblematic example is the way Cerf chooses local businesses to create a partnership with their shop: 'We visit all the enterprises, which must work in a specific way ... Before any contract, we take our time, we investigate and then we base our relationship even on trust and dialogue'. Another example is the will to find other people who share the same ideals: "I am in a lot of associations here and I try to do some good around me [...] Moreover I had a band and I've been playing for 6 years now: if there are some eco-social-musicians we can try some riffs during the weekend!"

By analyzing the interviews, we found four main motivations for Ulisse and Cerf members: sustainability, sociality, technology and economy.

\subsubsection{Sustainability}

Sustainability can be a consequence like in Cerf's case, or a cause, like in Ulisse. In the first case, sustainability is not always what associates seek, but it comes out when actors follow the precise and ethical steps required by a local and volunteeroriented association. Sustainability as a cause implies that it is the cause of members' actions. In this case, sustainability is learnt and studied because, as many students affirm, they look for a "change of paradigm".

The president of Cerf often mentioned a sustainability shift as the main drive of their customers: "our customers are willing to pay even a little bit more (not too much) to have a reliable and good quality product, linked to the environment and the territory". Sustainability is a very rooted drive for Cerf: for example, they are building an electric car park to encourage carpooling and green mobility as the president 
said "This car park has been thought specifically for environmental and sustainability purposes. Germaine's citizens must think about the environment. This is perfectly in line with our beliefs and at the very base of community's survival".

These pieces of conversations correspond to the "planet" motivation in (Böcker and Meelen, 2017). As a customer of Ulisse said: "I try to live a life as consistent as possible with my ideas... I think this is the strongest revolution we can propose [...] I could go to the local market but the Ulisse knows better than me, they select the sellers, I wouldn't be able to choose the right seller at the local market since I would like to respect millions of criteria: independent farmer, no pesticide, km0 etc. I refuse to buy from big chains and eat fast food, even if sometimes I am extremely tempted by 50 cents tomatoes from the supermarket wrapped in $1 \mathrm{~kg}$ of plastic".

Words appear to be followed by practice since in the field observation we had the opportunity to observe how vegetables are grown in the University's yard with their own compost, and also how the vegetables used to be picked from the farmer's house on the way back home by one of the members: these two practices aim to cut the carbon emissions of selling local products. Discord is always used to agree on who is "driving around there" (the farmer's house). Another example is the absence of plastic in Cerf's shops and in all Ulisse's initiatives.

The idea of a local community is always related with the issue of sustainability: to start something sustainable or to oppose lobbyism and consumerism - which are both not conform to the sustainability principles - it is necessary to start from a local community or from a group of stakeholders which have an expertise on the ongoing situation. The concept of sustainability is fundamental, not just because of the recent challenges and emergencies, but even as an idea that should always be included and embedded in every social or socio-technical research (Volpato et al., 2019; Poderi and Dittrich, 2018; Dourish, 2010; Cinderby et al., 2014).

Whether as a cause or as a consequence, having members motivated in making the world more sustainable, lead both associations to have behaviours labelled as "sustainable", which is aligned with the kind of products they sell.

\subsubsection{Sociality}

"We're not just an enterprise". Social motivation is slightly different for the two associations. While Ulisse's members want to find new friends with a similar vision or with which being engaged in projects, Cerf members are oriented towards socioeconomic mutual aid, with the aim of reinforcing the local community through a sense of community and relationships among members. An example from Ulisse is The Discord channel group for organising a Secret Santa "all in line with our ideals and food kmO" and the requests to "have a beer with someone downtown because tonight I am bored". 
While a member of Cerf said "We're partners with two Foundations that deal with social and solidarity economy [...] We're mostly made up of volunteers and each one of them has a different position. There is the café group that organises all related to the bistro; there is the shop group [...], there is the tourism group [...]. We take care first of our citizens and we want to take care of youngsters' needs. We want to promote links and connection among people. Not by chance meetings are always in physical presence, we talk face-to-face, especially because we can take advantage of our spatial proximity. Human links are important".

Another very important part related to Ulisse sociality is linked to the way they use Discord conversations. In the general channel or sometimes in thematic ones, they ask for recommendations related to environment or eco-friendly behaviours, like some permaculture techniques, for instance: "has someone bought a BeeHotel? Do you know if it is better to orientate them to the north or to the south?" or "You should pass from Bank $X$ to bank $Y$, which have very interesting projects related to wildlife conservation, even if unfortunately they are very small [...] everything is better than banks $A$ and $B$ ". This means that Discord and informal conversations ended up being a huge and very important knowledge repository.

The attention of social and relational aspects led members to create very close ties whether friendship-like (especially in Ulisse) or more supportive like in Cerf, enhancing the sense of community among members.

\subsubsection{Technology}

"Close to reality". This sentence has been said by the website designer when she explained the kind of technology Cerf needed. We think that a human-centered vision of technology is what Ulisse and Cerf have in common. For Ulisse, the ecology of artifacts is technology-centric, tries to be independent, and extremely creative and open source thanks to every contribution: "we're a little bit nerds" as one member said. For Cerf the ecology of artifacts is low tech, both as an ideological choice - "we want to rely on people" - and a forced choice, since a lot of members and customers are not familiar with digital technology.

Technology is even seen as a challenge: some members of Ulisse are intrigued by the perspective of matching their passion for coding, design or technology with the possibility to be useful. Members would like to be independent, both technologically and ideologically: "We wouldn't like to use Facebook or Whatsapp to communicate: we do not see ourselves on the same page [...] But it's impossible so far not to use them, especially because we are small and we want to be reached by everyone" said the organizer of the ride-sharing project. Similarly, a piece of Discord conversation shows: "Oh, if you know how we could share documents without Google, you're welcome!". But even on the choices people make for their everyday life, both for 
themselves and inside the association, like "I don't have Whatsapp, actually I don't even have internet on my mobile" (showing a very old mobile). The members of Ulisse also agree on "... using Discord. First of all your data is protected there. And you can create textual or voice channels for different topics. You can find people with your interests faster. You can even make video conferences. The problem is that it is not free and not open source".

All the members agree to use their own device for "public benefit" and to share the meeting rooms they manage to book at the university with others so that they can have spaces for meetings or debates.

Their initiatives as an association are moved by their values: social benefit, sustainability, and human centered technology: "We believe in an Engineering that can change how things are now, in engineers' engagement". Said the president of the students association.

Similar to technological independence is the right claimed by the president of Cerf of being disconnected and not using technology. More than technological independence here is a wish for an independence from technology, but these are two faces of the same medal. Indeed, online interactions can be seen as a complement and a support of offline ones, and often, what is classified online such as social coordination, invitation, offer, request, or collective action, encourage offline action (López and Farzan, 2015). As assessed by Lòpez and Farzan, the local activities are mostly off-sites ("we privilege face-to-face relationships", confirms the president of Cerf) and community goals are achieved by an entanglement of on-site and offsite, rising at any rate, users' social capital. This is even synthetized by the President's words: "our advantages are mostly based on people's energy, their competences, especially from our partners and the volunteers [...] The importance is harmonizing logistic and conviviality".

We observed that Facebook was used as an update tool (like a newsletter) for off-site actions, and the low response level on Cerf's Facebook page did not correspond to an equal low participation in events and activities taking place offline: the President himself stated that their events ranged from 50 to 120 participants and their touristic events are as well very popular.

Moreover, as noticed by (Satchell and Dourish, 2009), non-use is a form of use and can have a nuanced meaning, instead of being "labelled" or "pathologized". In Cerf, some forms of non-use happened because of lagging, especially with elderly members: "I have Whatsapp just to communicate with my daughter in Scotland, and some younger expert friends help me with computer and smartphone problems". Some of them might even be discouraged by some form of physical impairment like illness or low sight, falling partially in the category of the disenfranchisement (Satchell and Dourish, 2009). The website creator for Cerf said that she kept in mind to create a website that leaves the possibility to have a paper substitution to internet orders. 
The second non-use category happened with the displacement, very familiar to rural HCI and technological stewardship (Jayathilake et al., 2017; McMillen et al., 2020). In our case, people decided to rely on others, namely sons/daughters or neighbours when it came about using the technology, especially buying online. Similarly, in Cerf the "heavy" use of technology (design, website, creation of advertisements ...) is mostly on the hands of the professionals, namely the website creators.

A more complex example of non-use comes from Ulisse: despite they are all engineers' students, they try to limit the technological part of their community ecology of artifacts because of their environmental convictions. Even more interesting is their collaboration with a group of university professors and philosophers which are part of the low-tech movement. Taking an example of a Discord conversation about a new Facebook post on reading recommendations for the summer, a member said: "I recommend Philippe Bihouix: Low tech age and Happiness was for yesterday. We must promote our adhesion to the low-tech movement. And then a little bit of Collapsology won't harm anyone: read some books from Pablo Servigne".

The very wide range of technology related behaviours make it difficult to predict and label a typique user's relationship with his/her constellation of technologies: each time is necessary to "go to the field", interview, and avoid oversimplifications of this very complex issue.

\subsubsection{Economy}

Cerf is supporting forms of sharing that do not fall into two opposite poles - capitalized sharing economy or pure altruism. The president of Cerf presents the association as aiming to revive the local economy; he says that they have created the association/community to help people and their territory, and even that they are not just economy-based, implying that the economic and generally opportunistic component is present. As shown even by Bødker et al. (2016), to speed up or make possible some necessary processes in order to make a volunteering association work properly, some members had to be externally motivated: altruism (volunteering in this case) and ideals was not enough. Specifically they report the example of the web designer, which had to be paid in order to have the right mix of intrinsic (beliefs and ideas) and extrinsic (reward) motivation to pursue his job which had become too demanding and time consuming to be done in due time just in the name of ideals (which anyway, were present).

Cerf and Ulisse's sellers have chosen such partners and they do not sell to other more lucrative lobbies, already embed sustainability and local-loyalty values. The president of Cerf is clear on this purpose: their partners are strictly selected and very highly motivated to pursue a certain idea of production and marketing. 
A stable and self-run infrastructure would allow members of local communities to be in line with their motivations, and, reversely, it would allow members to shape their artifacts ecology. Our aim is then to go from this analysis of motivations to implications for designing for a community ecology of artifacts.

\subsection{Motivation-centered Design}

The first way to support local communities in designing their ecology of artifacts may be to help them in identifying the different motivations that drive their members to act in the community. For so doing, we suggest four personas (Nielsen, 2018) that represent the four kinds of motivations that we have identified. Personas should help the communities to combine motivations, the artifacts in use and socio-economic background, in order to co-design meaningful products or services, aligned with their common mission, and to define a common future.

Motivations are what represent the stakeholders' push to participate in the community, leaving very little space for assumptions. In addition, clearly defined motivations can be tested and refined in successive design phases, during workshops for instance.

Concretely, we think that the four personas could be used in role-play workshops $^{1}$ (Seland, 2006) with some of the community members to allow them both to identify themselves with the various personas and to reflect on what they want as a community at large. This kind of workshop could even take place without the presence of a professional designer. The advantage of role-playing is that participants have to adopt different points of view: It would be a precious resource for associations with members having very different aims, and to foster discussion among stakeholders. This could help different stakeholders to understand each other, to be able to frame a common problem (Steyaert et al., 2007), and to be able to create a story usable in other situations, for instance in marketing and social media management of the association.

The four personas we have identified from our analysis of motivations to participate in local communities are: user (Figure 6.1), volunteer (Figure 6.2), producer (Figure 6.3), and worker (Figure 6.4). We now explain the link between motivations and personas, and describe each persona.

The sociality motivation consists of a desire for affiliation, a wish for networking, for feeling part of a community, a group or something more close-knitted than society-at-large. We then created a persona called volunteer since volunteering is

1. https://www.designkit.org/methods/36?ref=publicdesignvault 


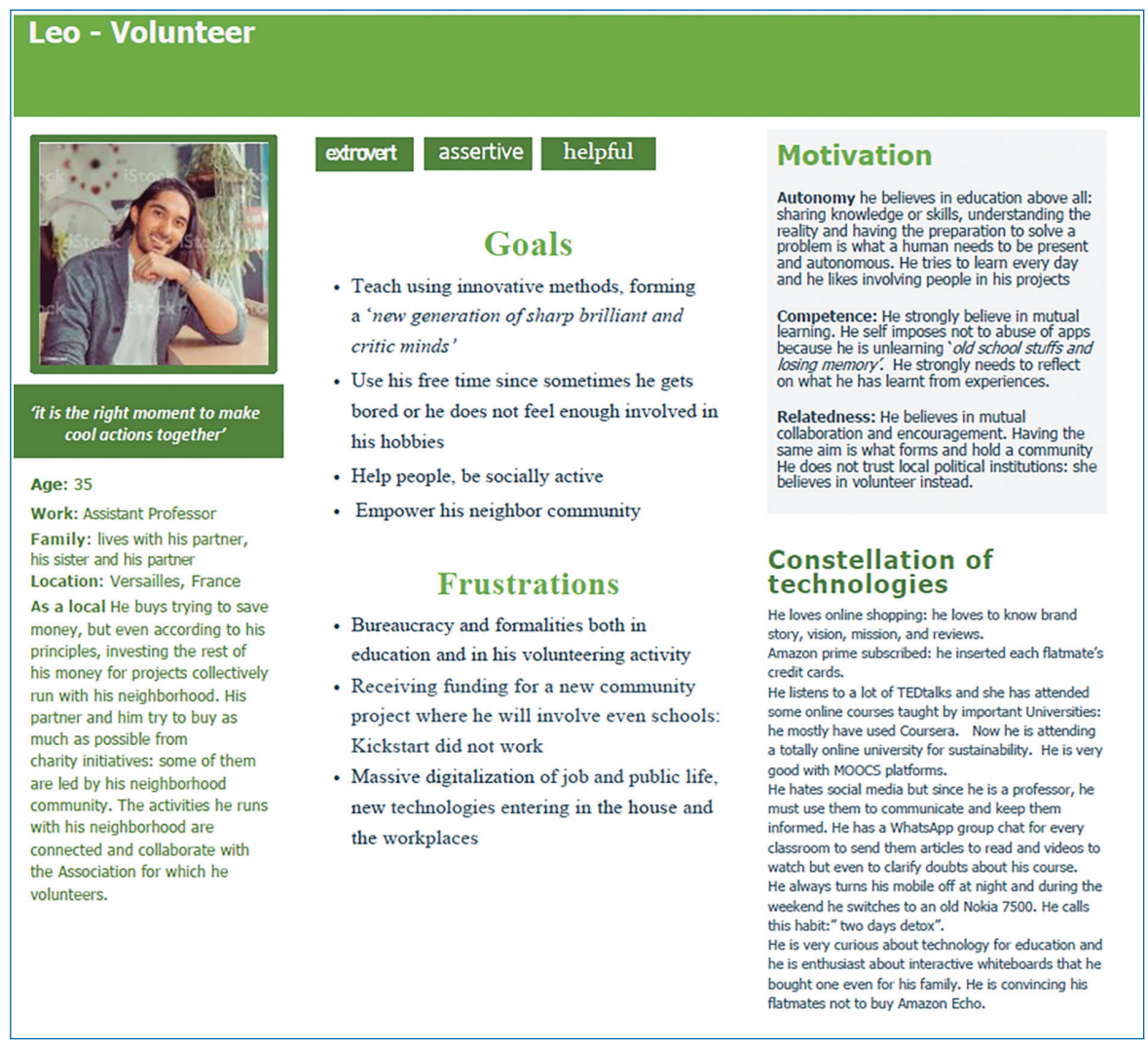

Figure 6.1. Persona volunteer.

the best way to fulfill all the listed aims consistently with one own values (in Ulisse and Cerf cases, environmental-related values).

The sustainability motivation led us to suggest a persona named the user, in other words the consumers of the associations.

The political motivation is related to mature political consciousness mixed with active social engagement: the person is conscious and concerned that his/her action has both political and social consequences. Both user and volunteer personas correspond to this motivation.

The economic motivation describes the profitable and more opportunistic part, so we created a persona called the seller, and another one called the worker, specifically referring to Cerf, which aim is even to "give a job to people".

The following sensitizing scenario (Waern et al., 2020) that involves the four personas illustrates the complex and multifaceted issues local communities face.

Leo wants to change his habits and he feels it is time to be more useful to other people: for this reason, for months now he is reading about non-profit organizations and associations aiming to help people and the planet. He has found an online 


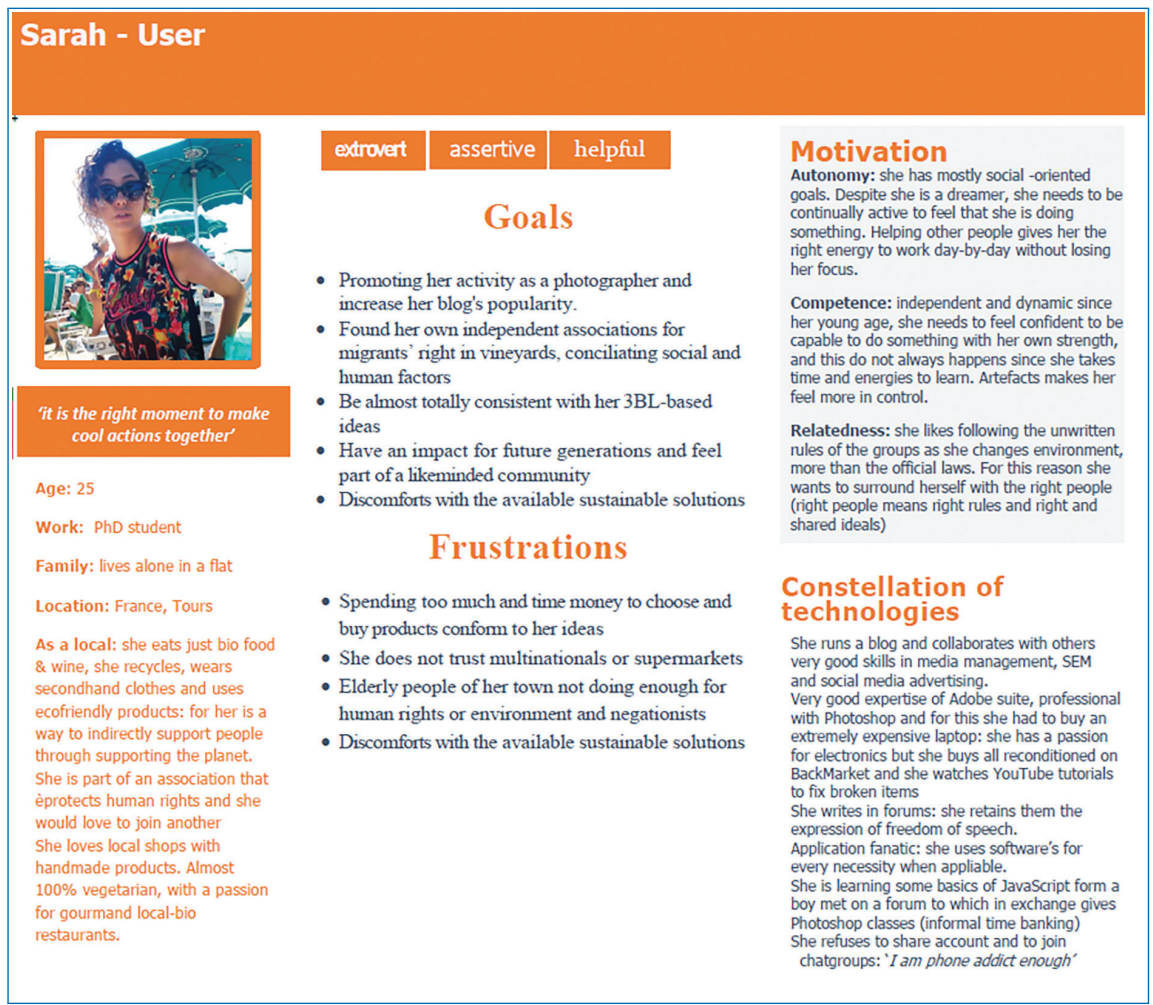

Figure 6.2. Persona user.

article from Sarah, a freelance journalist, about a local association where she is a regular customer, dealing with zero-waste products to replace polluting or disposable ones. Since during the past year Leo has been spending a considerable amount of his time looking on the Internet for anything that would have replaced little by little all the tools and items that do not conform to his environmentalist values, Leo decides to visit the website of the association. He finds it very business-oriented; the association owns a few shops that are run half by volunteers, half by workers that sell only local "replacement" products. The Facebook page of the association depicts pictures of a usual workday with some comments of colleagues or regular customers, and posts of the latest news related to the shops and the events. Scrolling down the products' list from the main website, Leo decides to visit the closest shop, and before, he asks to the official Instagram profile of the shop, ran by a volunteer, Lucas, if he can bring some old jars (in case they would find it useful for containing zero-packaging food). Lucas asks by SMS to the president of the association if it is possible. The president wants to push the association more and more towards a "green" vision and she specifically enjoys being personally in contact with the associates. The President then replies that yes, they might need as many jars as 


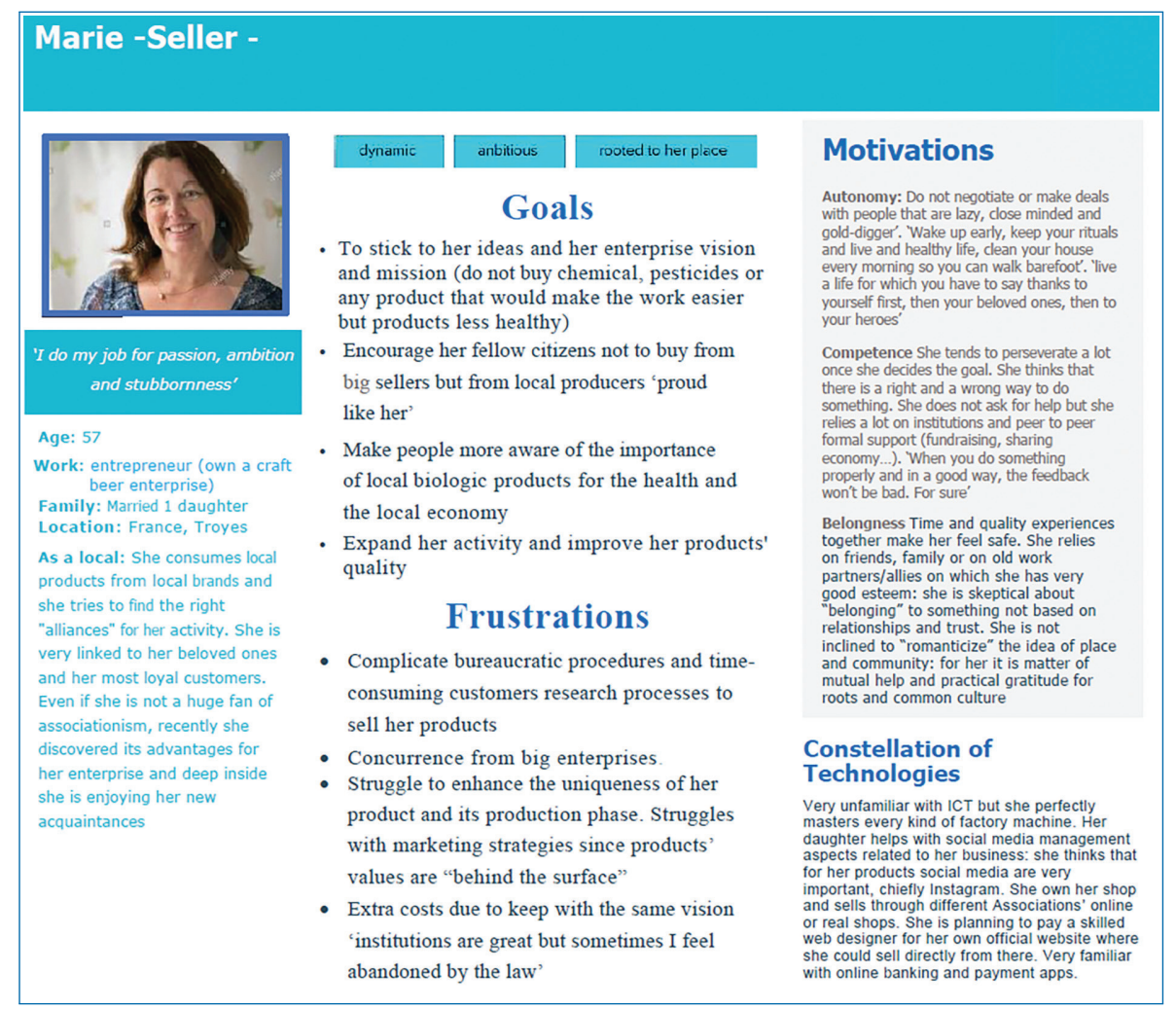

Figure 6.3. Persona seller.

possible: not because there is a plan for them, but who knows which amazing idea those jars would inspire to the associates. For this reason, she decides to share pictures of the jars in the group conversation, asking for suggestions. According to her, every member should share ideas and unused objects. Thus, Leo goes to the shop to give his jars. While visiting the shop, he notices that there is even the possibility to fill paper surveys, positioned right close to the cash register. So before leaving people can write a feedback on a piece of paper and leave it in a big box. He is very impressed by the range of products available, way more than the ones displayed online, so he reports his opinion directly to the shop assistant, Lucas, which encourages him to contact the web developer, who works for an enterprise. Leo decides to talk with the web developer and since he has some web-design skills, he decides to join the volunteers' group just to change some features and some colors of the landing page. He then asks the approval of the Association main runners. Once he has done this, he remembers that he saw some very creative beer bottles and he would like to buy some. He checks the catalog of the main sellers of the Association and he finds Marie, a producer specialized in hop cultivation. Leo decides to contact her through the association and he makes a request. Marie responds that 


\begin{tabular}{|c|c|c|}
\hline \multicolumn{3}{|l|}{ Lucas - Worker - } \\
\hline $\begin{array}{l}\text { 'I was just looking for a job, but this } \\
\text { association is doing so nice things' } \\
\text { Age: } 46 \\
\text { Work: association's shop clerk } \\
\text { Family: Re-married, } 3 \text { sons } \\
\text { Location: Reims, France } \\
\text { As a local: He is a PlayStation } \\
\text { fan and he invites all his friend } \\
\text { and their families to join him } \\
\text { and his wife: those gatherings } \\
\text { became central for his "niche" } \\
\text { of friends, which somehow } \\
\text { formed a community of } \\
\text { interests. Even the associates } \\
\text { love spending time together in } \\
\text { his place and they often meet } \\
\text { there for Association meetings } \\
\text { or just for an evening afterwork } \\
\text { with good food from the shop's } \\
\text { unsold (or expired). } \\
\text { By posting on Instagram and } \\
\text { Pinterest his outdoor activities is } \\
\text { giving visibility to local } \\
\text { landscape and sport attractions. } \\
\text { He buys (or brings back) food } \\
\text { from the local shop for which he } \\
\text { works }\end{array}$ & $\begin{array}{l}\text { eteative Generous Weighty } \\
\text { - Have an honest and interesting job which } \\
\text { ensure him a fair monthly income and keep } \\
\text { him passionate } \\
\text { - Found a "repair cafe" atelier in the Association } \\
\text { where he works } \\
\text { - Combine work and family life, ensure a future } \\
\text { to his sons, but also have the right amount of } \\
\text { free time for himself } \\
\text { - Have a lifestyle that respects his ideas and } \\
\text { beliefs: since he is working for the Association, } \\
\text { he is paying more attention to his choices, } \\
\text { especially related to food }\end{array}$ & $\begin{array}{l}\text { Constellation of } \\
\text { tech nologies } \\
\text { He is often online (especially when the shop is } \\
\text { empty) consulting Facebook and some websites, } \\
\text { usually online illegal film streaming ones. He is a fan } \\
\text { of YouTube tutorials and of the updates related to } \\
\text { Play Station and games. Once in a moth he plays } \\
\text { online role game. He is a very discrete player on the } \\
\text { net. However, he does not have real digital } \\
\text { competencies and skills: for example, more than } \\
\text { once his wife warned him that he believed to a fake } \\
\text { new. He borrows and lends games for Playstation } \\
\text { and he occasionally shares his Netflix accounts when } \\
\text { some of his friends asks him if they can watch a } \\
\text { specific movie. } \\
\text { He shares an Instagram profile with his wife. Since } \\
\text { they both are very sporty, they use it mostly have a } \\
\text { monothematic profile. Eventually they equipped thei } \\
\text { mobile for adventurous days out and to film sports } \\
\text { without the risk of breaking it. This shared passion } \\
\text { lead them to raise money on the "scaled sharing } \\
\text { platform" wawn.ratchworknresenticem to buy a } \\
\text { professional Gopro and other useful tools. He came } \\
\text { to know about this fundraising website from one } \\
\text { associate and he found the idea so genial that he } \\
\text { sent the website all over his group chats }\end{array}$ \\
\hline
\end{tabular}

Figure 6.4. Persona worker.

it is possible and asks her bottle supplier for an out-of-order. Then, the product is sent to the shops as "reserved for Leo" while the payment already happened online, using the website as an intermediary.

If local communities could benefit from the work of designers, web designers or user researchers, the personas presented should be taken into account when designing artifacts. Indeed, conformity to community's ideals and needs is necessary to move towards platform collectivism, which, as mentioned in Section 2, fosters a sense of community and is more sensible to issues that are important for the members we have interviewed: privacy and participative democracy. Platform collectivism is intimately related to Woodbourne's idea of sharing nicely, in contrast to the "capitalistically platformised sharing". The four personas give a snapshot of the users' motivations and attitudes that might be found in a local community interested in social, economic, and environmental sustainability. Therefore, taking all of them into account when designing the artifacts ecology should allow to align this ecology with users' values and to pursue community and users' motivations. 


\subsection{Conclusion}

In this chapter, we started by discussing sharing in local communities, stating that we are interested in the way an ecology of artifacts could support sharing nicely. We then described how two associations with common characteristics (strong sustainability ideology, involvement in the local economy, minded alike users and infrastructures, locality, strong autonomy) share nicely through their community's ecology of artifacts. Our analysis led us to identify four kinds of motivations for sharing nicely: sustainability, sociability, politics, and economy. We then derived four personas and a scenario from these motivations, and explained how we envision the use of personas and scenarios for supporting the design of a community ecology of artifacts that would embrace all the different motivations.

The contribution of this chapter is then twofold: On one side, we shed light on the motivations of participants in grassroots initiatives, understanding what pushes them to share nicely. In the cases that we studied, the ideals related to the protection of the environment and socio-political change co-exist with the need to earn money, get a job, and health improvement through better food. Those findings are consistent with the existing work about the triple bottom line model, which foresees that sustainability can only be realized through the coexistence of three interwoven factors: environment, society and economy (Elkington, 1997). Even if our approach aims at supporting the design of a community ecology of artifacts, the technology is not the focus, nor the "user" is, but we rather pay attention to the diverse motivations of participants. We consider motivations the first thing to address when conducting design research with communities, and throughout the community's life and evolutions. Consequently, the second contribution concerns how to address those motivations in grassroots initiatives that, as said, are strongly ideals and/or needs driven. The personas we propose aim at re-thinking technology both for society and communities, focusing on people instead of platforms (Avram et al., 2019; Srnicek, 2016). Therefore, we offer the personas to anyone who can make the difference in a local context: designers, NGOs, policymakers, and not for profit organizations. On this wavelength, as Ann Light and colleagues (Light et al., 2017) state, design should not accept things to be done "as usual", since we are facing extraordinary times characterized by a "wave of change and uncertainty". CSCW and HCI have their role in changing society and imagine a better future to pursue and realize through design and humancentered technology. Targeting the right change-makers is fundamental to start this process. 


\section{References}

Avram, G., Choi, J.H., Paoli, S.D., Light, A., Lyle, P., and Teli, M. (2019). Repositioning CoDesign in the age of platform capitalism: From sharing to caring. CoDesign, 15(3), 185-191. https://doi.org/10.1080/15710882.2019. 1638063

Bellotti, V., Ambard, A., Turner, D., Gossmann, C., Demková, K., and Carroll, J.M. (2015). A muddle of models of motivation for using peer-to-peer economy systems. CHI 2015 - Proceedings of the 33rd Annual CHI Conference on Human Factors in Computing Systems: Crossings, 1085-1094. https://doi.org/10.1145/ 2702123.2702272

Belk, R.W. (2014). You are what you can access: Sharing and collaborative consumption online. Journal of Business Research, 67(8), 1595-1600.

Bødker, S., Korsgaard, H., and Saad-Sulonen, J. (2016). 'A Farmer, a Place and at least 20 Members': The Development of Artifact Ecologies in Volunteer-based Communities. Proceedings of the 19th ACM Conference on Computer-Supported Cooperative Work \& Social Computing, 1142-1156. https://doi.org/10.1145/ 2818048.2820029

Böcker, L. and Meelen, T. (2017). Sharing for people, planet or profit? Analysing motivations for intended sharing economy participation. Environmental Innovation and Societal Transitions, 23, 28-39. https://doi.org/10.1016/j.eist.201 6.09.004

Braun, V. and Clarke, V. (1 January 2006). Using Thematic Analysis in Psychology. Qualitative Research in Psychology, 3, 77-101. https://doi.org/10.1191/1478 088706qp063oa.

Carroll, J.M. and Beck, J. (2019). Co-designing platform collectivism. CoDesign, 15(3), 272-287. https://doi.org/10.1080/15710882.2019.1631353

Cinderby, S., Haq, G., Cambridge, H., and Lock, K. (2014). Practical Action to Build Community Resilience: The Good Life Initiative in New Earswick. 74.

DeWalt, K.M., DeWalt, B.R., and Wayland, C.B. (1998). "Participant Observation.” pp. 259-99 in Handbook of Methods in Cultural Anthropology, edited by H.R. Bernard. Walnut Creek, Calif.: AltaMira Press.

Dourish, P. (2010). HCI and Environmental Sustainability: The Politics of Design and the Design of Politics. In Proceedings of the 8th ACM Conference on Designing Interactive Systems - DIS '10, 1. Aarhus, Denmark: ACM Press, https: //doi.org/10.1145/1858171.1858173.

Elkington, J. (1997). Cannibals with forks. In: The Triple Bottom Line of 21st Century. Capstone Publishing Ltd., Oxford, UK. 
Feigin, S., Owens, G., and Goodyear-Smith, F. (2014). Theories of human altruism: A systematic review. Annals of Neuroscience and Psychology, 1(1). Retrieved from http://www.vipoa.org/neuropsychology

Hawlitschek, F., Stofberg, N., Teubner, T., Tu, P., and Weinhardt, C. (2018). How Corporate Sharewashing Practices Undermine Consumer Trust. Sustainability, 10(8), 2638. https://doi.org/10.3390/su10082638

Jayathilake, H.A.C.K., Jayasinghe-Mudalige, U.K., Perera, L.D.R.D., Gow, G.A., and Waidyanatha, N. (2017). Fostering technology stewardship approach to promote knowledge sharing among farming communities in Sri Lanka. Tropical Agricultural Research, 28(3), 238-246. https://doi.org/10.4038/tar.v28i3.8228

Keyes, O., Hoy, J., and Drouhard, M. (2019). Human-Computer Insurrection: Notes on an Anarchist HCI. Proceedings of the 2019 CHI Conference on Human Factors in Computing Systems, 1-13. https://doi.org/10.1145/3290605.3300 569

Kuutti, K. and Bannon, L.J. (2014). The turn to practice in HCI: Towards a research agenda. Proceedings of the SIGCHI Conference on Human Factors in Computing Systems, 3543-3552. https://doi.org/10.1145/2556288.2557111

Lay, J.C. and Hoppmann, C.A. (2015). Altruism and Prosocial Behavior. In N.A. Pachana (Éd.), Encyclopedia of Geropsychology (pp. 1-9). Springer Singapore. https://doi.org/10.1007/978-981-287-080-3_69-1

Light, A. and Miskelly, C. (2015). Sharing Economy vs Sharing Cultures? Designing for Social, Economic and Environmental Good. 14.

Light, A., Shklovski, I., and Powell, A. (2017). Design for Existential Crisis. Proceedings of the 2017 CHI Conference Extended Abstracts on Human Factors in Computing Systems, 722-734. https://doi.org/10.1145/3027063.3052760

López, C. and Farzan, R. (2015). Lend me sugar, I am your neighbor!: A content analysis of online forums for local communities. Proceedings of the 7 th International Conference on Communities and Technologies - C\&T '15, 59-67. https://doi.org/10.1145/2768545.2768558

Manzini, E. (2015). Design, When Everybody Designs: An Introduction to Design for Social Innovation. Translated by Rachel Coad. ISBN 978-0-262-02860-8. The MIT Press Cambridge, Massachusetts, London, England.

McMillen, H.L., Campbell, L.K., Svendsen, E.S., Kealiikanakaoleohaililani, K., Francisco, K.S., and Giardina, C.P. (2020). Biocultural Stewardship, Indigenous and Local Ecological Knowledge, and the Urban Crucible. https://doi.org/10.5 751/ES-11386-250209

Mauss, M. (2002). The Gift: The Form and Reason for Exchange in Archaic Societies. Routledge.

Norström, A.V., Cvitanovic, C., Löf, M.F., West, S., Wyborn, C., Balvanera, P., Bednarek, A.T., Bennett, E.M., Biggs, R., de Bremond, A., Campbell, B.M., 
Canadell, J.G., Carpenter, S.R., Folke, C., Fulton, E.A., Gaffney, O., Gelcich, S., Jouffray, J.-B., Leach, M., ... Österblom, H. (2020). Principles for knowledge co-production in sustainability research. Nature Sustainability, 3(3), 182-190. https://doi.org/10.1038/s41893-019-0448-2

Ostrom, E. (1990). Governing the Commons: The Evolution of Institutions for Collective Action. Cambridge University Press.

Parguel, B., Benoît-Moreau, F., and Larceneux, F. (2011). How Sustainability Ratings Might Deter 'Greenwashing': A Closer Look at Ethical Corporate Communication. Journal of Business Ethics, 102(1), 15. https://doi.org/10.1007/s1 0551-011-0901-2

Poderi, G. and Dittrich, Y. (2018). Participatory design and sustainability: A literature review of PDC proceedings. Proceedings of the 15th Participatory Design Conference on Short Papers, Situated Actions, Workshops and Tutorial-PDC '18, 1-5. https://doi.org/10.1145/3210604.3210624

Rossitto, C., Bogdan, C., and Eklundh, K. (2014). Understanding Constellations of Technologies in Use in a Collaborative Nomadic Setting. Computer Supported Cooperative Work (CSCW). 23. 10.1007/s10606-013-9196-4.

Ryan, R. and Deci, E. (1 February 2000). Self-Determination Theory and the Facilitation of Intrinsic Motivation, Social Development, and Well-Being. The American Psychologist 55, 68-78. https://doi.org/10.1037/0003-066 X.55.1.68.

Satchell, C. and Dourish, P. (2009). Beyond the user: Use and non-use in HCI. Proceedings of the 21st Annual Conference of the Australian Computer-Human Interaction Special Interest Group on Design: Open 24/7 - OZCHI '09, 9. https: //doi.org/10.1145/1738826.1738829

Seland, G. (2006). System Designer Assessments of Role Play as a Design Method: A Qualitative Study. 10.

Srnicek, N. (2016). Platform Capitalism. John Wiley \& Sons.

Steyaert, P., Barzman, M., Billaud, J.-P., Brives, H., Hubert, B., Ollivier, G., and Roche, B. (2007). The role of knowledge and research in facilitating social learning among stakeholders in natural resources management in the French Atlantic coastal wetlands. Environmental Science \& Policy, 10(6), 537-550. ht tps://doi.org/10.1016/j.envsci.2007.01.012

Teli, M., Di Fiore, A., and D'Andrea, V. (3 April 2017). Computing and the Common: A Case of Participatory Design with Think Tanks. CoDesign 13(2), 83-95. https://doi.org/10.1080/15710882.2017.1309439.

Volpato, T., Allian, A., and Nakagawa, E.Y. (2019). Has social sustainability been addressed in software architectures? Proceedings of the 13th European Conference on Software Architecture - ECS '19 - Volume 2, 245-249. https://doi.org/10.1 $145 / 3344948.3344979$ 
Waern, A., Rajkowska, P., Johansson, K.B., Bac, J., Spence, J., and Løvlie, A.S. (2020). Sensitizing Scenarios: Sensitizing Designer Teams to Theory. Proceedings of the 2020 CHI Conference on Human Factors in Computing Systems, 1-13. https://doi.org/10.1145/3313831.3376620

Woodburn, J. (1998). Sharing is not a form of exchange: an analysis of propertysharing in immediate-return hunter - gatherer societies. In Property relations: renewing the anthropological tradition (ed. Hann C.M.), pp. 48-63 Cambridge, UK: Cambridge University Press [Google Scholar]. 